\title{
The Croatian Diaspora in North America: Identity, Ethnic Solidarity and the Formation of a "Transnational National Community"
}

IVANA DURIC

\section{IN T R O D U C T I O N}

This article presents the results of an empirical study examining the impact of democratization, ethnic tensions and the conflict situation in Croatia on the self-perception, ethnic homogenization, and the process by which a "transnational national community" developed among the Croatian diaspora in North America. The main methodology used in this research is a discourse analysis of articles published in the Fraternalist during the period 1980-1995. The Fraternalist is the official journal of the Croatian Fraternal Union (CFU), the most influential Croatian diasporic organization in North America. For the purpose of this study, only articles describing the activities and attitudes of members of the Croatian diaspora toward their homeland were taken into consideration.

Loring M. Danforth defines a diaspora as a social entity that "...consists of people who left their homeland either voluntarily or by force, and who have an awareness of constituting a minority immigrant community in the host country in which they have settled." According to Robin Cohen, the main feature that distinguishes diasporic from other kinds of immigrant communities is a strong emphasis on group identity and a refusal to totally assimilate into the host society. Members of the group are stretched between two countries and two loyalties. This is particularly the case with first generation immigrants for whom the native country is the main point of their collective thoughts and efforts. Moreover, diasporic communities tend to feel an obligation to influence the home society by all possible means. ${ }^{2}$ Greece, Ireland, and Israel serve as illustrative examples of the impact that diasporic communities can have on the process of struggle for a separate nation-state. In those cases, nation-state formation was supported by large, well-organized diasporic communities, ${ }^{3}$ which have exercised a "long tradition of active participation in the nationalist struggles of their homelands." 
Diasporic organizations and newspapers can play an important role in raising a distinctly ethnic consciousness. Benedict Anderson has examined the role of the press in enabling and strengthening feelings of ethnic consciousness and in the success of diasporic communities in preserving their distinctiveness. ${ }^{5}$ In this paper, the Croatian diaspora in North America is considered as a community of immigrants acting within their host countries to influence affairs back home. Despite the fact its members are scattered all over the United States and Canada, the Croatian diaspora managed to strengthen an ethnic consciousness and solidarity that reached its peak at the beginning of the war in Croatia in 1991 (though one could also argue that the conflict served to foster the diaspora's ethnic feelings). Finally, special attention should be paid to the role of modern communication in this process since it enabled the diaspora to respond rapidly and to initiate a variety of activities (political and humanitarian) directed at both the host and home societies. Moreover, new means of communication facilitated the emergence of a so-called "transnational national community" that is understood, according to Danforth, to mean "national communities... being constructed on a transnational scale."

The importance of the North American Croatian diasporic community lies primarily in its size, which has been approximated at from one to 2.5 million (the population of Croatia in the 1991 census was about 4.7 million). ${ }^{7}$ Together with a long tradition of organizing, the North American Croatian diasporic community is also characterized by its concern, interest, and participation in Croatian politics. Although a variety of Croatian organizations are active in North America, the Croatian Fraternal Union (CFU) is the oldest and largest. Boasting around 100,00o members, this union is one of the most influential of the Croatian diasporic organizations. The CFU enjoys a certain influence on local authorities and is therefore widely accepted as a legitimate representative of the Croatian ethnic community in the U.S. and Canada. The official tools with which the CFU helps to influence or even create the community's public opinion are the weekly Fraternalist and the radio station, Voice of the CFU.

The Fraternalist has been published since 1904, and currently enjoys a readership of around 40,00o. ${ }^{8}$ Due to its "middle of the road" editorial policy, the Fraternalist was available in Croatia even during the Communist period, thus providing an informational exchange between the diaspora and the homeland. At the same time, the majority of other émigré publications, particularly those with certain political agendas and tendencies against the Yugoslav regime, were forbidden.

The period from 1980 to 1995 has been chosen in order to trace the process of political development and raising an ethnic and political consciousness, which was followed by the wide mobilization of the Croatian diasporic community. Accordingly, the research findings can be divided into two main periods. 
The first lasts from the death of Yugoslav President Josip Broz Tito in May 1980 until 1988-89 and covers the weakening of the Yugoslav Communist regime and the beginning of the process of democratization. The second covers the first democratic elections in May 1990, the proclamation of Croatia's independence in 1991, as well as the period of war.

THE ENFORCEMENT OF ETHNIC IDENTITY AND THE MOBILIZATION OF THE NORTH AMERICAN CROATIAN

D I A S P O R A

Among articles published in the Fraternalist during the period from 1980 to 1995, a special place is given to those devoted to the strengthening of ethnic identity in its readership. A number of articles deal with Croatian history, often glorifying the memory of famous Croatian politicians such as Stjepan Radić and Ante Starčević, the founding fathers of Croatian national politics in the nineteenth and twentieth centuries. Culture is another popular topic, with numerous portraits of Croatian writers, priests and other famous personalities (for example, Cardinal Alojzije Stepinac, Countess Katarina Zrinska, etc. $)^{9}$ that nourish ethnic pride. Religion was rather neglected in the Fraternalist's writings until the first shy obituaries appeared in the early 1980s, stressing the religious affiliation of the deceased, something previously not mentioned. Later, the Fraternalist published messages from the Croatian Catholic clergy addressed to the diaspora as well as publicizing their visits. All the elements of ethnic identity in Anthony D. Smith's terms ${ }^{10}$ can be found in the Fraternalist's discourse between 1980 and 1995. Culture, history, myths, language and religion were instrumentalized in the process of ethnic homogenization and served as the first stage of diasporic political mobilization. The Yugoslav (Croatian) language dispute in the second half of the 198 os over renaming the official Croatian language "Croato-Serbian" occurred at a focal point of the diasporic community's collective strivings. Failure to preserve a distinctive name for the language instigated collective distress among the Croatian diaspora and led to an outbreak of recollections of other historical injustices, especially those during the twentieth century. In addition, the reinterpretation of national history, particularly of the Bleiburg victims, ${ }^{11}$ of demographic losses during World War II, ${ }^{12}$ of the Croatian Spring ${ }^{13}$ and of the campaign for the placement of the Ban Josip Jelačić's monument, served as powerfully motivating symbols that set in motion the process of ethnic homogenization and mobilization.

\section{Language}

The mobilization of the Croatian diasporic community for the U.S. census in 1981 can be identified as one of the first steps in the process of the diaspora's homogenization. A campaign was organized in the Fraternalist, advising every 
American citizen of Croatian origin to declare him/herself a Croat, and his/her mother tongue Croatian. ${ }^{14}$ The census was expected to reflect the size of the community and, in turn, define the level of financial support that each group would receive from the U.S. government.

However, these statistics did not reflect diasporic reality. The disuse into which the Croatian language had fallen among Croatian Americans was noted at the autumn session of the CFU in 1982, as well as the lack of qualified teachers and the danger that the Croatian language might disappear among the diasporic community within next 15 years. ${ }^{15}$ At the same meeting, English was declared the official language of the CFU (few readers were able to read in Croatian). By the early 1980 s, the process of the Croatian diaspora's losing their native language was entering its final phase. Quite unexpectedly, political developments in Croatia inaugurated efforts among the Croatian diaspora to protect and promote the Croatian language. The promotion of Croatian among the diasporic community took two main forms in the second half of the 1980s. One focused on the "old homeland" - and protested attempts to change the official title of the Croatian language in the Constitution of the Socialist Republic of Croatia. ${ }^{16}$ As expressed in one letter:

Apparently, there is a movement in Yugoslavia to have the name "hrvatski knjizevni jezik" (Croatian literary language) deleted from the Constitution of the Republic of Croatia. If Croatian people exist, the Croatian Socialist Republic exists, and we can certainly say that the Croatian literary language exists and should continue to exist. If we allow [it]... then we are being denied our very existence as a people. If we want to continue to exist as a Croatian people and maintain our ethnic identity, for which we strive here and in the homeland, then we as Croatians in emigration and in Croatia should not be denied the name of our language which makes us distinct from any other people in the world... ${ }^{17}$

Reacting to this threat, the Croatian diaspora started a fund-raising campaign to establish the first Department of Croatian Language and Culture outside of Croatia, at York University in Toronto, Canada. ${ }^{18}$ Despite the diaspora's public appeals and lobbying, the official name of the Croatian language was changed to Croato-Serbian in 1989.

The second way Croatian was promoted was to reverse the under-representation of the Croatian language and personnel in the Serbo-Croatian section of the Voice of America (VOA) radio station. The CFU initially requested that affirmative action be introduced at the VOA and then demanded the creation of a separate Croatian section. The claim was made on the grounds that:

...the VOA carries an important message of democracy and serves as an indispensable source of alternate information in Yugoslavia's still relatively closed society. ... By retaining a combined "Serbo-Croatian" section, the VOA is missing an opportunity to reach and establish rapport and credibility with Croatian speakers. ${ }^{19}$ 
Underlying the distinctiveness of the Croatian language, yet another letter stressed that:

Suppression of the Croatian language in official American broadcasts not only offends the approximately 8 million Croatian-speaking listeners of Yugoslavia's population of 23 million, but it is also a barrier that keeps Croatian listeners away. ${ }^{20}$

The VOA's separate Croatian section was created in 1992 and "broadcast five (5) 30 minute live air-shows daily ${ }^{\text {“21 }}$ while its personnel was enlarged from two to five members in the first half of $1992 .^{22}$

\section{Religion}

Freedom of religious expression was another important issue in the process of ethnically mobilizing the Croatian diaspora in North America. During the Socialist period in Yugoslavia (1945-1990), religion was rather oppressed as Yugoslav religious diversity posed a threat to the Communist ideology of brotherhood and unity. In line with its espoused neutral position, the Fraternalist avoided emphasizing religious affiliation. It was not until the mid-1980s that an accent on religion could be found in the Fraternalist's articles. Religion was always more present and preserved among Croatian diasporic communities than in the home country because the Catholic Church took upon itself the role of custodian and set out to preserve a distinct Croatian ethnic identity, language and tradition among Croatian diasporic communities. ${ }^{23}$ As George J. Prpic stresses, it was "the Catholic churches that became the first centers of Croatian life."24 Moreover, due to the intolerant attitudes of Yugoslav authorities toward political émigrés, it was only the Church that secured the right to keep close relations and regular contacts with the Croatian diaspora without being punished for their activity. ${ }^{25}$ On the way toward ethnic consolidation, an important step was the publication of the annual "Encyclical to the Diaspora" ${ }^{26}$ in the Fraternalist in December 1986. Directed at the diaspora, it stressed the unity of the Croats in the homeland and the diaspora under the framework of the national Catholic Church.

After having met the need for national spiritual regeneration, focus shifted to the need for material renewal, and the reconstruction of churches became an important issue. After 1984, frequent calls for financial assistance to restore churches appeared in the Fraternalist, such as requests for the church in Sošice ${ }^{27}$ and the parish of St. Joseph in Zagreb. ${ }^{28}$

\section{Culture, history and myths}

As mentioned earlier, many articles in the Fraternalist recall the great tradition of Croatian national culture. Besides educational motives, these writings functioned to consolidate ethnic identity; they were a preparatory stage for ethnic homogenization. As one of the readers, Fr. Paul Maslach, stated: 
I am impressed by the many articles on history and culture. You are using history and culture as a learning tool: looking to the past and learning from it to bring about a better and more prosperous future, I certainly support your efforts... ${ }^{29}$

Already at the 17th convention of the CFU, which was held in September 1987, "the decision to cooperate with the Old Homeland was reached for the purpose of affirming and learning about the Croatian cultural tradition. ${ }^{30}$ In addition to intensifying the sphere of external cultural cooperation, i.e. with the home society, the CFU turned toward strengthening internal collaboration, among the different organizations of the North American Croatian diaspora. In 1990, the Croatian alumnae network - the AMAC (Almae Matris Alumni Croatiacae) - merged with the CFU. In an open letter published in the Fraternalist, the AMAC invited all its members to join ranks with the CFU under the pretext of "broad Croatian cultural action in North America." ${ }^{31}$ The letter evoked similar earlier attempts that had failed, stressing that:

By setting our goals in a realistic and reasonable way, by uniting in purpose and by respecting individuality in style and form, we can build a foundation for meaningful Croatian efforts in North America. ${ }^{32}$

Among the main goals set is for mutual participation in activities, "dissemination of unbiased information about Croats and Croatia" while the Fraternalist becomes "an open common forum for exchange of information, views and ideas of all AMAC/CFU members." ${ }^{33}$

The extension and solidifying of relations was not only directed at the cultural sphere but also toward reconciliation of the different political ideologies among the Croatian diaspora in North America. This relates particularly to the openings of the CFU's new lodges in Canada, where the largest percentage of post-World War II immigrants (the "newcomers") had settled. For many reasons this large segment of the Croatian diaspora had not joined the CFU. When the political situation in Croatia changed, however, and the appearance of ethnic homogeneity became desirable, it became necessary to reconcile and incorporate the opposing ideological streams among the Croatian diaspora. As a result, recollections of World War II disputes and debates began to appear in the 1980 os, challenging and reinterpreting what was prescribed as official Croatian history.

Back in the home society, amidst economic crises and galloping inflation that by 1985 had reached $70 \%,{ }^{34}$ Serbian nationalism expanded under the cover of democratization, as well as claims that "Croatia's Communists were committing 'cultural genocide' against the Serb community, ${ }^{35}$ recalling the atrocities committed during World War II. These accusations opened a space for old and unsettled disputes on the number and nationality of persons murdered in Jasenovac to be rehashed. Publication of Tomislav Sabljak's book Croatia and the Victims of World War II furthered this public discussion. The Fraternalist's 
response was to publish an article on the war victims, followed by an apology from the editors for raising the question and a promise not to do so again:

...Because CFU by-laws rule against instigating religious controversy and because we have many Serbian members enrolled in our society, it is only with the greatest reluctance that we have become involved in the controversy over the alleged massacres during World War II in the Jasenovac concentration camp in Croatia... We are printing Brother Beljo's story in response to those who would attempt to blame the Croatian people for the alleged murder of 700,00o to 1,200,00o Serbians. We consider this our final word on this subject and do not intend to open the pages of the Fraternalist to any further discussion on the matter. ${ }^{36}$

However, the discussion was just beginning and was to be recalled on many other occasions. ${ }^{37}$ Reopening the debate on war atrocities in 1985 met with approval among one part of the Fraternalist's readership, who responded emphasizing that "Croatians have been scapegoats for too long." ${ }^{8}$ Yet, it took several years for a final condemnation of all crimes to be issued, of those committed by Yugoslav partisans after World War II as well as those of the Ustashi regime during it. Significantly, on the 5oth anniversary of the Bleiburg events, it was the Croatian Catholic Church who issued an indictment of all the atrocities thus performing the role of mediator and conciliator. ${ }^{39}$

The year 1987 brought about a change in the Fraternalist's official discourse toward Croatia. Instead of its usual "middle of the road policy," a discussion began on the historical events of World War II in order to bridge gaps within the Croatian nation. Certainly, the debate appeared as a reaction to nationalistic Serbian claims and Serbian xenophobic roll-calls hinting at collective Croatian guilt for the atrocities of the Ustashi regime during World War II. The first step toward an all-Croatian reconciliation was the redefinition of recent history. A letter from Lucian Reichherzer reflects this aim; it is quite controversial in the way he denies the similarity between the Fascist and Nazi movements, claiming that the Ustashi "just wanted a sovereign Croatia." ${ }^{40}$ In immediate response to this viewpoint appeared the complaint of John Strizic, who protested against the CFU's nationalistic and linguistic propaganda, expressing regrets at much of what was being published. He stressed that:

Our membership is predominantly American and Canadian born and educated. To them, the Old Home's linguistic and national exclusiveness are the ninth hole in the flute... Only a small number are interested in the homeland of their ancestors... Under the coverage of history and language, some of the newcomers are distorting our lines. ${ }^{41}$

Moreover, Strizic reflects negatively upon attempts to misuse the CFU for nationalistic politics (as Reichherzer did in his letter) and the extremist émigré's dreams to return to power in Croatia.

Responding to this letter, Ante Beljo thanks Strizic for his remark that the younger generation of migrants is going in the same direction as the extremists 
- "a Croatian direction, the direction of our future and [I] hope that all of us will realize it... That is the only direction for a better future of Croatia and of the CFU..." Beljo condemns those who preach the solution according to which the best is when one group rules Croatia, while the opposition is exiled to a wood, prison or to emigration, concluding that everyone should be equal and equally interested in Croatia's welfare. ${ }^{42}$

An initiative presented to U.S. Congress to erect a monument to Draža Mihailović, a Serbian Chetnick leader during World War II, served to pour oil on the already flaming debate. The CFU immediately responded by sending an open letter to Congress, strongly opposing the idea and condemning:

....any attempt to glorify or to erect a monument honoring the dreaded Nazi collaborator... The CFU will always decry acts of terrorism and/or atrocities be they by Croatians, Serbians or by Nazi collaborators against the forces of decency. ${ }^{43}$

The Fraternalist invited all members to contact their representatives in Congress and complain. The protest was then extended to the targeting for public attack of the Rev. Djuic, a Chetnick war criminal still alive and residing in the U.S. Although the campaign lasted for several months, it was not as successful as previous ones had been. Unlike Andrija Artuković, a Ustashi member and minister during the NDH (Independent Croatian State) who was extradited to Yugoslavia and indicted, Rev. Djuic died peacefully in his American home. Certainly, the outcome left a rather biased impression, creating feelings of discontent among the Croatian diaspora, as did anti-Chetnick articles, ${ }^{44}$ which not only reflected the defensive position of the diaspora but also helped to reaffirm assertions that Croatians were scapegoats. Once again, traumatic memories and history worked towards creating intra-ethnic homogeneity while at the same time widening the interethnic gap.

THE DIASPORA'S POLITICAL ENGAGEMENT

Until the beginning of the 1990s, an interest in American domestic affairs prevailed among the Fraternalist's readership. However, an interest in developments in Croatia was never absent. During the first half of the 1980s, there were articles reprinted occasionally from the Croatian newspapers Vjesnik and Večernji list. Until 1986, most of these reprinted articles were related to the living conditions in Croatian villages in Dalmatia, Lika and Gorski kotar - where the majority of Croatian Americans came from. After 1986, however, articles on the openings of new waterworks or asphalt roads in far-away villages were replaced by reprints from Croatian and American newspapers devoted to the political developments in Yugoslavia. This change in the content of the Fraternalist was initiated primarily by the wider process of democratization and the disintegration of the Eastern European Communist block. At the same time, 
economic crises and galloping nationalism sharpened the political situation in Socialist Yugoslavia. The CFU's readership was well aware of what was going on in Yugoslav (Croatian) politics. Reports on the Yugoslav Communist leaders' meetings, conferences, news and analyses of the situation in Kosovo and the abolition of its autonomy in 1988 often appeared in the Fraternalist.

Prior to the final dissolution of Yugoslavia and the beginning of the democratic processes in Croatia, the Croatian diaspora was very much in favor of secession from Yugoslavia. This kind of feeling is best expressed in a 1987 letter to the editor by N. Bilandzich:

...Those elements in Yugoslavia which are at present in control must understand that the Croatian people will never give up their rights to liberty, justice and self-determination. We want freedom and independence, and for this we do not owe an apology to anyone. In today's Croatia, foreign elements can sing and hoist their flags, but if the Croatian people do the same, they are declared an enemy of the state and placed in jail. Mr. Editor, we Croatians are slaves in our own homeland. If you examine our historical past, I am sure that you will be able to conclude that we Croatians have done so much to advance the cause of Slavism and Yugoslavism, which has brought us nothing more than oppression and misery. For this reason, I am and always will be for Croatian independence and liberty. ${ }^{45}$

As already cited, a similar opinion is expressed in another letter which underlines that "a nation without its independence is like a homeless person living in someone else's home as a servant or slave." ${ }^{46}$

At the end of the 1980s, the Fraternalist very carefully followed the developments in Croatia towards democratization and a market-oriented economy as well as the introduction of pluralism and a multi-party system. The Fraternalist paid particularly close attention to the efforts made to found new political parties. Among the earliest attempts closely followed by the Fraternalist is the case of the Croatian Democratic Union (CDU) ${ }^{47}$ under the leadership of Franjo Tudjman. The CDU is described in the Fraternalist as the most widespread and the best known opposition party in Croatia and among the Croatian diaspora. ${ }^{48}$ The success of its efforts to "attract money and expertise from Croats living abroad..." ${ }^{49}$ also receives mention. The Fraternalist found it necessary to respond immediately to allegations of having made a financial contribution to the CDU:

The Society cannot and will not endorse any political party. We don't even do this in the United States or Canada because our members are free to select their own political party... We do recommend candidates who are members of the Society, but that is as far as we will go in becoming involved in political parties; ... we disclaim all those rumors being circulated that the Croatian Fraternal Union is financially contributing to any political party in Croatia..$^{50}$

The first multi-party elections since World War II were scheduled for April 22 (the first round) and May 6,1990 (the second round). The diaspora was pleased by a letter from the CDU to the Croatian Assembly requiring voting privileges 
for "gastarbeiters" and Croatian emigrants (those that were still citizens of the Socialist Republic of Croatia), and freedom for political emigrants to return. ${ }^{51}$ However, participation in the elections was approved only for those with permanent resident status in Croatia, under the condition that they had to come to Croatia and vote in the country. ${ }^{52}$ In spite of Communist reluctance to allow the diaspora to vote, the CDU won the elections, taking $60 \%$ of the seats while the overall turnout was $85 \%$.

\section{The Diaspora's main activities during the war in Croatia}

The political events surrounding Croatia's declaration of independence and the eruption of war in the autumn of 1991 caused a rapid mobilization of the Croatian diaspora. A protest rally against the disarmament of the Croatian police forces, held in Toronto on January 26, 1991, brought together 15,00o Croatians and other supporters. Soon afterward, the CFU openly proclaimed: "...in this time of great danger we must stand together." ${ }^{23}$

The events in Croatia had a direct impact on the Croatian diasporic community in North America in proving "that they [members of the diaspora] are an organic part of their nation, the most directly connected with its destiny, although far away from Croatia." ${ }^{54}$ Access to technological advancements allowed many Croatians in North America to stay in daily contact with their relatives in Croatia. Their feelings about affairs in Croatia are best revealed in CFU President Bernard Luketich's statement:

I think all of the people who consider themselves descendants of the Croatian heritage are very concerned and interested in what is taking place in the homeland of our parents, grandparents and relatives..$^{55}$

With the Croatian diaspora's political agitation and their financial and material assistance to the newly created Croatian $a r m y^{56}$ and communities and towns that were under attack, the community appeared more strongly united than ever.

Responding to an official appeal from the Croatian Government, ${ }^{57}$ numerous written petitions and telephone campaigns to the White House and the U.S. Foreign Affairs Committee were initiated, expressing dissatisfaction with the level of American support for the new Croatian democracy. Although U.S. authorities recognized Croatia's independence in the beginning of 1992, and assisted in the deployment of UN troops, the largest problem for Croatia remained the arms embargo. In 1993, the Croatian diasporic community called for a "united Croatian front," recognizing the importance of creating a Croatian lobby, which was later accomplished through the foundation of NFCA (the National Federation of Croatian Americans) on January 23, $1994 . .^{58}$ 


\section{Humanitarian Aid}

CFU responded instantly to the news of fighting and refugees in Croatia. A campaign was launched to collect donations, "...to help our sisters and brothers suffering from the consequences of terrorist attacks in Our Homeland." ${ }^{\prime 59}$ In early August, the "Croatian Humanitarian Aid Fund" was established. ${ }^{60}$ By the beginning of September 1991, the fund had already collected \$70,0oo US, ${ }^{61}$ while donations had reached $\$ 850$, ooo US by the end of June $1993 .{ }^{62}$ By July 1,1992 , 155 containers of humanitarian relief had been sent to Croatia. ${ }^{63}$ In addition, another fund, "Hrvatska akcija za život" (Croatian Action for Life), was launched in the Fraternalist in April 1992, the main aim of which was to accumulate donations for children who had lost fathers in the war.

The outburst of hostilities together with the ensuing humanitarian activities marked the final stage in the process of the "transnational homogenization" of Croatians. As Daniele Conversi points out, it was the "international danger [that] strengthened national unity" ${ }^{\prime 64}$ among both parts of the Croatian ethnic community - within Croatia and abroad.

\section{MEDIA, GLOBALIZATION AND DIASPORA}

The diasporic community's involvement in the political problems in Croatia was a result of processes of globalization which allow for an extension of national communities through the emergence of "transnational national communities" (Danforth 8o). Loring M. Danforth stresses the importance of homelands for diasporic communities "... in shaping their sense of collective identity. People of the Diaspora continue to be members of the nations whose homelands they have left behind" (80). Among the most important predispositions for diasporic participation is a new democratic experience that motivates the diaspora to lobby on behalf of the homeland. If the group has a high level of education and prosperity, this, of course, helps. Often, academic "networks" are established in order to promote and actively participate in both the host and home society's activities (Danforth 91).

Still, the crucial issue turns out to be modern communication technologies. Danforth identifies the influence of new communication technologies and improved transportation that enable the diaspora to participate to a much greater extent in the politics of the homeland. He stresses that new technologies, satellite telecommunications networks, e-mail, and faxes allow constant contact with the home-country and instant response, while the speed of inter-continental air travel enables people to be involved in the life of two or more countries simultaneously:

The 'primordial sentiments' of region, ethnicity, language and religion globalize (Appadurai 1990), spreading throughout the world to unite vast networks of people who re- 
main loyal to a national homeland they no longer inhabit. National communities are not being replaced by transnational ones, they are being constructed on a transnational scale. (Danforth 80).

The mobilization of and political pressure exercised by the Croatian diaspora as well as their numerous efforts to collect humanitarian aid immediately after war broke out in Croatia confirm his theory.

According to Danforth, newspapers are a traditional source of information that keep people "informed of political developments in their homeland through ethnic media, which often reproduce material directly from sources in the national capital" (8o-81). However, the speed of this information has proven unsatisfactory, encouraging the introduction of new computer-based information exchange systems such as the Croatian Electronic Network (founded in 1990): "These computer links have provided an organized news distribution service which has proven invaluable to us here in North America during the war for obtaining the latest information." ${ }^{65}$

Since May 1991, one hour Croatian radio news broadcasts have been transmitted daily throughout North America. ${ }^{66}$ The radio broadcasts (in English, German and French) were among the earliest means which had "...a significant impact on creating the true image of Croatia. Our people were informed so they could inform, in their turn, their friends, neighbors, and fellow citizens. ${ }^{167}$ In addition, in January 1994, a special satellite Croatian TV program for North America was introduced (central TV news broadcasting one hour per day). Almost at the same time, beginning on February 10, 1994, an agreement was established with SPAN cable TV to transmit the main daily news.

The Croatian government recognized the importance of developing modern communication means for disseminating information and interacting with diasporic communities early on. It counted on the political support of the diaspora as well as recognizing that the diaspora were significant financial contributors to the new Croatian state. ${ }^{68}$

\section{CHANGES IN THE CFU'S ATTITUDES TOWARD CROATIAN P O L I T I C S}

The war situation in Croatia produced a high level of ethnic homogenization and solidarity among the diaspora and engaged all possible means of influence, whether financial or political. Logically it was to be expected that sooner or later this homogeneity and unity would be exhausted or begin to decline. One of the first riffs was of a rather benign nature and related to a campaign to rename streets. A street in the Croatian capital Zagreb named after Josip Marohnic, a founding father and the first president of the Croatian Fraternal Union, was renamed, which surprised CFU membership and led to discord. After much protest, Marohnic's name was given to another street. 
Another set of misunderstandings resulted from financial matters. The CFU had been very generous in its assistance to Croatia during the war, promoting unity among all Croats in the face of war. But the CFU's members became frustrated due to the large number of appeals coming from Croatia for their financial assistance. A letter from CFU member, M. Popp, reveals this concern: "Now there are several groups and organizations coming around with their hands out. Many of us are dubious about their cause and wonder if these moneys are just going into their pockets." ${ }^{69}$ Similarly, the CFU president became irritated by the variety of demands of CFU non-members:

...who feel that the individual project which they are working with is the most important item of concern for our Croatian people. ... Every day we receive some request for financial assistance from non-members of the organization who feel that just because they are Croatians and have worthy projects, our society should financially support their requests. Again we remind all, the Croatian Fraternal Union's prime concern is to financially support members of the Croatian Fraternal Union. ${ }^{70}$

In addition, it seems that one more reason for CFU dissatisfaction was their low profile in Croatia: the CFU was rarely mentioned in Croatian public discourse despite its generous help. A reprint from Večernji list surmises the reason lies in the CFU's reluctance to get involved "in local Croatian political trickery". ${ }^{71}$

\section{CONCLUDING STATEMENT}

In the period from 1980 to 1995, the Croatian Fraternal Union was transformed from a politically passive and rather neutral organization into one that took a more active role articulating the political adherence of North American Croatians and their support for political changes in the home society of Croatia. Across the Fraternalist's pages, there was a constant flurry of activity intended to solidify the diaspora's ethnic identity. Moreover, it could be argued that the process of ethnic homogenization was set off by Croatian independence and the eruption of war in the summer of 1991 . The CFU became actively involved in the democratic process through the wide political mobilization of its members. These activities included protests organized in Washington in 1988 against the abolition of the Croatian language's official status in socialist Croatia, and those in 1991 encouraging U.S. foreign policy to put a stop to the war in Croatia.

During the 198 os and until the beginning of the war, there was a definite strengthening in the ethnic identity of members of the Croatian Fraternal Union. Issues central to this process are the self-identification that began with the 1981 U.S. census campaign, and language, a strong emphasis on religion and common culture through the continuous publication of articles on Croatia's heroic history, its national heroes, ideologists, priests, writers and poets, which served to revive common memories, a sense of unity and of ethnic identity. It seems that the diaspora's organ served as a useful link in the mobilization of the 
Croatian national movement, in keeping with Benedict Anderson's argument that the periodical press is of crucial importance in the emergence of national communities. In a sense the diasporic press provides not only news from both the host and home countries, but it also constantly reproduces elements of group identity among immigrants. In line with this argument, it should be also noted that besides ethnic mobilization and solidarity, extensive use of new electronic tools and information technologies, such as the Internet, e-mail, special radio and TV broadcasts via satellite, etc., enabled the emergence of a "virtual transnational national community."

NOTES

1 Danforth, Loring M. The Macedonian Conflict. Princeton: Princeton University Press, 1995. 80.

2 Cohen, Robin. Global Diasporas: An Introduction. London: UCL Press, 1997. 23-26.

3 Seton-Watson, Hugh. Nations and States. London: Basil Blackwell, 1979.

$4 \quad$ Arjun Appadurai, cited in Danforth, 8o-81.

5 See Benedict Anderson, Long Distance Nationalism: World Capitalism and the Rise of Identity Politics (Berkely: Center for German and European Studies, 1992) and Imagined Communities: Reflections on the Origin and Spread of Nationalism (London: Verso, 1983).

6 Danforth 80.

7 According to the 1991 census, there were 4,784,265 inhabitants in Croatia (State Bureau of Statistics).

$8 \quad$ "The CFU distributes its bulletin Zajedničar (Fraternalist) free of charge to over 40,00o addresses in North America." Open letter to the friends and alumni of the University of Zagreb, Fraternalist, September 26, 1990: 2.

For example, there is an article on the 16oth birthday anniversary of Dr. Ante Starčević in the Fraternalist, June 22, 1983: 12.

9 The 310th commemoration of Katarina Zrinski's death, June 28, 1983: 12.

$10 \quad$ Smith, Anthony D. National Identity. London: Penguin Books, 1991.

${ }_{11}$ Bleiburg is the place near the Austrian-Slovenian border where the Ustashi army that surrendered to the Western Allies in May 1945 were passed back to Tito's partisans and slaughtered. During the Socialist period, mention of this event was forbidden.

12 Another widely discussed issue was the exact number of people murdered by the Ustashi in the Jasenovac concentration camp during World War II, see Tomislav Sabljak, "Žrtve drugog svjetskog rata" (Victims of World War II), Fraternalist, August 2, 1989: 15 .

13 The Croatian Spring was the liberal movement in Croatia during 1968-71. It was led by Croatian Communist Party functionaries and broken up in 1971 when many involved were imprisoned for the threat they posed to the Yugoslav federation. See Vinko Grubišić, "Hrvatsko proljeće: dvadesetak godina kasnije" (The Croatian Spring: Twenty Years Later), Fraternalist, November 1, 1989: 13-14. The monument is a historical symbol of the Croatian struggle for freedom in the $19^{\text {th }}$ century. It was finally returned to the main square in Zagreb on May 23, 1990. Initially the horseman's sword pointed north symbolizing Croatian resistance to Hungary and 
Austria, while today it points south. See "Spomenik banu Jelačiću”, (The Ban Jelacic Monument), Fraternalist, October 10, 1989: 12.

14 "The dutiful and necessary response of all people of Croatian descent is to reply 'Croatian,' in order to identify oneself as a proud descendent of Croatian lineage" (“American Croatians to Fill In 1980 Census," Fraternalist, July 26, 1980: 1).

15 "Report," Fraternalist, April 16, 1982: 17.

16 "...plans are for public discussions on this subject and there is a proposal that the official language be "Croatian and Serbian. ... Only for the Republic of Croatia is there a proposal for an official dual language, so if such a proposal is good for Croatia, why isn't it also proposed for all the other Republics of Yugoslavia?" ("About Our Society That Cares," Fraternalist, December14, 1988: 2).

17 "About Our Croatian Language," Fraternalist, April 6, 1988: 2.

18 "Katedra Hrvatskog Jezika i Kulture" (The Department of Croatian Language and Culture), Fraternalist, March 4, 1987: 14.

19 “Croatian 'Voice' Needed," Fraternalist, August 2, 1989: 2.

$20 \quad$ "Letter To The Editor," Fraternalist, September 13, 1989: 2.

${ }_{21}$ Voice of America - International Broadcasting Bureau http://www.voa.gov/ croatian/

${ }_{22}^{22}$ "Letter To The Editor," Fraternalist, July 15, 1992: 2.

${ }^{23}$ See case studies on this topic: Josip Kumpes, "Napomene o religiji, crkvi $i$ etničkom identitetu (na primjeru Hrvata u Madarskoj)" (Remarks on Religion and Ethnic Identity (The Case of Croats in Hungary), Migracijske teme 63 (Zagreb: 1990): 363-70; and Mirjana Domini, "Gradišćanski Hrvati - zajedništvo usprkos granica (osvrt na sudbinu ogranka gradišćanskih Hrvata u Mađarskoj)" (The Gradisce Croats - Unity Despite Borders (Remarks on the Fate of the Gradisce Croat Branch in Hungary), Migracijske teme 63 (Zagreb: 1990): 325-34.

24 Prpic, George J. The Croatians in Greater Cleveland. Cleveland: 1985. 8.

25 "Posjet kard. Kuharića i msgr. Stankovića Hrvatima u dijaspori" (Cardinal Kuharic and Msgr. Stankovic Visit the Croatian Diaspora), Fraternalist, January 23, 1991: 11, 13 .

${ }^{26}$ "Iseljenički dan-28.12.1986" (The Diaspora Day - 28.12.1986), Fraternalist, January 28, 1987: 14, 18.

$27 \quad$ Fraternalist, February 22, 1984: 20.

28 Fraternalist, November 4, 1987: 20.

29 "Letter to the Editor," Fraternalist, November 29, 1989: 2.

so "Suradnja s Domovinom" (Cooperation with the Homeland), Fraternalist, September 1987.

${ }^{31}$ "Open Letter to the Friends and Alumni of the University of Zagreb," Fraternalist, September 26, 1990: 2.

32 ibid. 2.

33 "Open Letter to the Friends and Alumni of the University of Zagreb," Fraternalist, September 26, 1990: 2.

34 Tanner, Marcus. Croatia: A Nation Forged in War. New Haven and London: Yale University Press, 1997. 207.

35 ibid. 212.

$36 \quad$ Fraternalist, January 18, 1985.

37 For example, Ante Beljo's article on Croat victims during World War II, Fraternalist, February 22, 1989: 12, 14.

$38 \quad$ "Editorial," Fraternalist, January 30, 1985: 2.

39 This is revealed in the following quotation: "However, May 1945 is remembered 
in Croatia as the month of the terrible slaughter of imprisoned soldiers and civilians turned over to the Yugoslav Army by the Western Allies. Remembrance of this suffering is closely connected with Bleiburg and a forced death march referred to as 'The Way of the Cross'... On the other hand, actions taken by the regime in Croatia, founded on an ideology of racial and national exclusivity, led to vengeance and indefensible acts that must be called crimes." "Croatian Bishops Recall the End of the Second World War", Fraternalist, May 10, 1995: 4, 21.

$40 \quad$ "...The Ustashi wanted only to liberate their country from the Serbian yoke and be independent, which they once were when they had their own kings etc. Their goal was separation from Yugoslavia. It can be compared to the struggle of the Basques in Spain or the Kurds in Turkey or the Armenians in Turkey or the Irish in Ulster. A nation without its independence is like a homeless person living in someone else's home as a servant or slave" ("Letter to the Editor," "A Brief Historical Review of the First 5o CFU Years," Fraternalist, June 3, 1987: 2).

${ }_{41}^{41}$ "Pregled vijesti: Bratstvo i nacionalizam" (News Review: Brotherhood and Nationalism), Fraternalist, August 19, 1987: 21.

42 "Croatian solidarity - all for one and one for all - is our Croatian motto even more today than it ever was in the past. We are the sons of former Croatian domobrans, partisans, Ustashi and who knows what other colors and camps - we respect them as our fathers, but adamantly refuse to repeat their suicidal fights no matter how much some individuals will be angry with us." Ante Beljo, "Pisma" (Letters), Fraternalist, October 28, 1987: 16. Drazha Mihailovich was a Serbian Chetnick commander, and his troops rescued two American pilots that crashed in Yugoslavia during World War II.

43 "We Dare Not Honor Traitors," Fraternalist, February 6, 1985: 1-2.

44 "Povampireno četništvo" (The Vampire-like Chetnicks), Fraternalist, January 8 and January 15, 1986: 14; and "We Don't Want Any State of Yours," Fraternalist, February 26, 1986: 4.

45 "Letter to the Editor," Fraternalist, January 9, 1985: 2.

46 "A Brief Historical Review of the First 50 CFU Years," Fraternalist, June 3, 1987:

2.

47 In Croatian - Hrvatska demokratska zajednica (HDZ).

48 "Pogledi i misli o Hrvatskoj" (Views and Thoughts on Croatia), Fraternalist, March 21, 1990: 12.

49 "Tudjman Plans Sovereign State," Fraternalist, June 6, 1990: 4.

50 "Freedom and Democracy," Fraternalist, February 14, 1990: 2.

${ }^{51}$ "Pismo HDZ Saboru Hrvatske", (The CDU's Letter to the Croatian Assembly), The Fraternalist, 12 December, 1989. p. 8

${ }_{52}$ "Tko može glasati na izborima u Hrvatskoj?" (Who Can Vote in the Elections in Croatia?), Fraternalist, March 28, 1990: 13.

53 Fraternalist, October 2, 1991: 13.

${ }^{54}$ "A Brief Historical Review of the First 50 CFU Years," Fraternalist, June 3, 1987: 25 .

55 "President Luketich Interviewed By Voice of America," Fraternalist, September 11, 1991: 15 .

${ }^{56}$ A fund-raising campaign in Los Angeles and San Pedro, CA to raise money to buy uniforms for Croatian soldiers raised \$55,0oo US. See Fraternalist, November 20, 1991: 14 .

${ }^{57}$ "We ask that you serve as witnesses and interpreters in your respective countries. ... If you can, in any way, please influence the White House and Official 
Representatives of the US Government because the People of Europe are waiting to see what the BIG BROTHER has to say." Ante Kločinović speech. "Minutes: 18th Quadrennial Convention Monday, September 16, 1991, Fraternalist, January 8, 1992. Another appeal, "Hrvatima u Sad i Kanadi" (To Croatians in the USA and Canada), was issued by the Croatian government urging the Croatian diaspora to inform their local, state and federal authorities about the situation in Croatia (Fraternalist, July 3, 1991: 14).

58 "Zajedno do promocije Hrvatske" (Together for Croatian Promotion), Fraternalist, February 9, 1994: 11.

$59 \quad$ "Humanitarian Aid For Croatia," Fraternalist, July 31, 1991: 2.

6о "... actually was started in May by members of a Croatian Youth Theater group "Marin Držić”, from Berlin, Germany..." ("Humanitarian Aid," Fraternalist, August 7, 1991: 2 .

61 "Aid Fund Grows," Fraternalist, September 4, 1991: 2.

62 “Glas Hrvata-kao jedan glas” (All Croats As One), Fraternalist, June 30, 1993:

11.

63 Fraternalist, July $1,1992$.

${ }^{64}$ Conversi, Daniele. "Moral Relativism and Equidistance." This Time We Knew: Western Responses to War in Bosnia. Eds. Thomas Cushman and Stjepan Gabriel Mestrovic. New York: New York University Press, 1996.

65 Nenad Antonić, “E-mail Bridges The Ocean," Fraternalist, March 25, 1992: 17.

66 "Direktno iz Zagreba: Slušajte dnevnu jednosatnu emisiju" (Direct from Croatia: Listen 1 hour Daily News Program), Fraternalist, September 11, 1991: 14.

${ }_{67}$ Vladimir P. Goss, "Radio Zagreb Helps Create True Image of Croatia," Fraternalist, December 23, 1992: 19.

68 "Fast and qualitative information from the homeland is of extreme importance for all Croatian emigrants who want to participate and contribute to Croatia's economical prosperity." Ante Beljo, "Projekt satelitske veze sa Hrvatskom" (The Satellite Connection Project), Fraternalist, March 16, 1994: 12.

$69 \quad$ Milan N. Popp, "Letter to the Editor," Fraternalist, August 25, 1993: 27.

70 "President's Column - About Our Society That Cares," Fraternalist, June 24, 1992: 2.

${ }^{71}$ "Dijaspora iznad strančarenja" (Diaspora Beyond Partisan Quarrels), Fraternalist, September 7, 1994: 15. 